\title{
Buku Pengayaan Pembelajaran Cerita Fabel Berbasis Literasi untuk Siswa Sekolah Dasar
}

\author{
Moh. Fakhri Nuha1, Yuni Pratiwi², Nurchasanah ${ }^{2}$ \\ 'Pendidikan Dasar-Universitas Negeri Malang \\ 2Pendidikan Bahasa Indonesia-Universitas Negeri Malang
}

\begin{tabular}{l}
\hline \hline INFO ARTIKEL \\
\hline Riwayat Artikel: \\
Diterima: 13-01-2018 \\
Disetujui: 12-02-2019 \\
\hline
\end{tabular}

\section{Kata kunci:}

learning materials; fable story;

literacy;

buku pengayaan;

cerita fabel;

literasi

\begin{abstract}
ABSTRAK
Abstract: This research was aimed to produce a book supporting fable-based literacy learning for elementary school students. This research model adopted from the model 4D development. As for this research generates. First, the product was developed with a base of basic literacy. Second, the theme of the story is developed with reference to the student text book. Third, a character story using animals endemic to Indonesia. Fourth, the storyline was developed by integrating values character education. Fifth, equipped with practice questions to guide students' understanding. Sixth, the use of language is adjusted to the criteria of elementary school students. Seventh, the design of the illustrations presented in full and interesting so that it can develop the visual intelligence of students. Based on the results of validation tests, practitioner tests, field tests, and corrective actions of the products developed it is feasible to be implemented.
\end{abstract}

\begin{abstract}
Abstrak: Penelitian ini bertujuan untuk menghasilkan buku pengayaan pembelajaran cerita fabel berbasis literasi baca-tulis untuk siswa sekolah dasar. Model penelitian ini mengadopsi dari model pengembangan 4D. Hasil penelitian sebagai berikut. Pertama, produk dikembangkan dengan basis literasi baca-tulis. Kedua, tema cerita dikembangkan dengan mengacu buku teks siswa. Ketiga, tokoh cerita menggunakan binatang endemik Indonesia. Keempat, alur cerita dikembangkan dengan mengintegrasikan nilai-nilai pendidikan karakter. Kelima, memuat latihan pertanyaan untuk menuntun pemahaman siswa. Keenam, penggunaan bahasa disesuaikan dengan kriteria siswa sekolah dasar. Ketujuh, desain ilustrasi disajikan secara penuh dan menarik sehingga dapat mengembangkan keecerdasan visual siswa. Berdasarkan hasil uji validasi, uji praktisi, uji lapangan, dan tindak perbaikan produk yang dikembangkan telah layak untuk diimplementasikan.
\end{abstract}

\author{
Alamat Korespondensi: \\ Moh. Fakhri Nuha \\ Pendidikan Dasar \\ Universitas Negeri Malang \\ Jalan Semarang 5 Malang \\ E-mail: Fakhri.nuha95@gmail.com
}

Buku menyajikan berbagai bahan bacaan yang diperlukan masyarakat. Bahan bacaan yang dimaksud seperti buku teks yang terdapat di lembaga akademik maupun buku non teks yang sifatnya untuk sarana hiburan. Kathy dan Rebecca (2007) memberikan pandangan bahwa buku bacaan dapat membuka pintu citra diri yang mau berkembang menjadi lebih baik. Buku bacaan yang disajikan memberikan peluang bagi setiap individu untuk tumbuh dan berkembang. Salah satu jenis buku yang digunakan dalam lembaga pendidikan dasar adalah buku pengayaan. Keberadaan buku pengayaan diperkuat oleh Peraturan Menteri Pendidikan Nasional (Permendiknas) Nomor 2 tahun 2008 pasal 6 yang menyatakan bahwa selain menggunakan buku teks pelajaran, pendidik dapat menggunakan buku panduan pendidik, buku pengayaan, dan buku referensi dalam proses kegiatan belajar-mengajar. Parkinson dan Adendorff (2005) menjelaskan bahwa buku jenis ini selain ditujukan untuk dinikmati, juga dapat digunakan siswa untuk menunjang buku mata pelajaran. Buku pengayaan memiliki peran guna menunjang dan melengkapi sumber belajar yang sesuai dengan kebutuhan di sekolah.

Implementasi Kurikulum 2013 menuntut pembelajaran yang dilaksanakan diarahkan pada penguasaan beragam jenis teks. Siswa pada jenjang usia sekolah dasar dihadapkan dengan berbagai jenis teks yang harus di kuasai. Jenis teks yang dimaksud dapat dikelompokkan menjadi dua kategori, yaitu teks sastra dan teks faktual/informatif. Teks fabel menjadi salah satu teks sastra yang dibelajarkan pada jenjang sekolah dasar. Menurut Kuo (2012), cerita fabel merupakan fiksi yang secara spesifik memuat pembelajaran moral melalui para karakter binatang yang ditampilkan. Pembelajaran teks cerita fabel selain untuk membelajarkan moral juga untuk membelajarkan kemampuan berbahasa siswa. 
Menurut Hasanah (2012), melalui cerita dapat digunakan sebagai landasan tumpu dalam pembelajaran kemampuan berbahasa (literature based program) di sekolah dasar. Upaya yang dapat dilakukan untuk mengoptimalkan ketercapaian kompetensi tersebut dengan mengedepankan konsep kemahirwacanaan dalam proses pembelajaran. Kemahirwacanaan penting untuk dijadikan basis dalam proses pembelajaran siswa sekolah dasar di era perkembangan ilmu pengetahuan dan teknologi abad 21, terutama kemampuan literasi baca-tulis. Menurut Suyono (2006) kecakapan literasi secara umum terdiri atas tiga kegiatan inti yaitu membaca, menulis, dan berpikir kritis. Kemampuan tersebut perlu dimiliki oleh setiap individu sebagai syarat untuk berkomunikasi dengan orang lain, hal tersebut merupakan bagian dari hak dasar manusia yang menyangkut pembelajaran sepanjang hayat. Pembelajaran dengan memanfaatkan cerita berbasis literasi dirasa cukup penting guna mewujudkan generasi yang memiliki kemampuan kemahirwacanaan. Hal tersebut sepandang dengan yang dikemukakan oleh Maureen (2018) bahwa kemampuan literasi (literacy thinking) pada siswa sekolah dasar akan berkembang dengan sangat baik apabila memanfaatkan cerita yang disukai oleh siswa.

Siswa usia sekolah dasar dalam pembelajaran cerita fabel diarahkan pada proses pemberian pengalaman bersastra. Menurut Marcum (2007) anak pada usia tersebut sudah mulai memahami logika secara stabil dan berada pada tahap operasional kongkrit. Karakteristik anak usia tersebut ditandai dengan kemampuan anak dalam mengembangkan imajinasinya. Lebih lanjut menurut Huck (2017) anak usia sekolah dasar khususnya kelas rendah menyukai cerita hitam-putih, baik dan buruk dengan penyajian cerita yang relatif pendek. Oleh karena itu, buku cerita fabel dijadikan sebagai sarana untuk menanamkan nilai-nilai moral dan melatihkan kemampuan kemahirwacanaan kepada siswa kelas II sekolah dasar.

Berdasarkan hasil pengamatan di lapangan, diketahui bahwa cerita fabel pada dasarnya sangat digemari oleh siswa. Alasan siswa menggemari cerita fabel karena (1) cerita jenis ini dapat menghibur dan ringan untuk dibaca oleh siswa, (2) cerita fabel menampilkan tokoh binatang yang beragam sehingga siswa dapat mengidolakan tokoh pemerannya, (3) siswa dapat mengkaitkan dari teks cerita fabel dengan cerita modern yang mereka lihat difilm, sementara itu terdapat kesenjangan yang terjadi di lapangan, antara lain (1) ketersediaan buku penunjang dalam pembelajaran cerita fabel masih terbatas dan adapun buku cerita yang tersedia tergolong cerita fabel klasik serta tokoh binatangnya kurang bervariasi, hal ini membuat siswa kurang memperoleh pengalaman dari buku cerita yang mereka baca, (2) buku teks pelajaran siswa yang memuat pembelajaran cerita fabel rata-rata memiliki struktur teks yang panjang dan tidak dibantu dengan ilustrasi yang sesuai dan menarik, sehingga siswa merasa kurang antusias untuk membacanya, (3) siswa mengalami kesulitan dalam menggali informasi yang terdapat pada cerita fabel, hal ini yang menyebabkan siswa merasa kesulitan untuk menceritakan kembali cerita fabel tersebut. Berdasarkan hasil analisis kebutuhan dan permasalahan tersebut, guru menyarankan (1) perlunya memaparkan nilai moral kehidupan yang diintegrasikan dengan kehidupan nyata siswa, (2) perlunya latihan pertanyaan yang dapat menuntun pemahaman siswa, dan (3) perlunya untuk mendesain tampilan buku pengayaan yang menarik dan disesuaikan dengan karakteristik anak usia kelas II sekolah dasar, agar siswa antusias untuk membacanya. Berdasarkan latar belakang tersebut, maka perlu untuk melakukan pengembangan buku pengayaan pembelajaran cerita fabel yang memperhatikan kriteria-kriteria tersebut untuk mengatasi permasalahan yang terjadi di lapangan.

Terdapat tiga penelitian terdahulu yang relevan dengan penelitian dan pengembangan ini. Penelitian yang berkaitan dengan pengembangan buku pengayaan pernah dilakukan oleh Prasetyo (2017) dengan judul "Pengembangan Buku Penunjang Materi Kuliah Apresiasi Cerpen Untuk Penanaman Nilai Karakter Mahasiswa PBSI”. Penelitian tersebut menghasilkan produk berupa buku penunjang pembelajaran apresiasi cerpen yang memenuhi aspek kelayakan isi, penyajian, kebahasaan dan tampilan. Penelitian tersebut melaporkan bahwa materi apresiasi cerpen dapat dioptimalkan dengan adanya buku penunjang apresiasi cerpen. Penelitian tersebut memiliki perbedaan dengan penelitian ini, yaitu terkait dengan pembelajaran cerpen guna menanamkan nilai karakter pada tingkat mahasiswa, sedangkan penelitian ini terkait pembelajaran teks fabel pada tingkat sekolah dasar.

Penelitian yang berkaitan dengan pembelajaran teks fabel pernah dilakukan oleh Rohmatul (2016) dengan judul "Pengembangan Bahan Ajar Menulis Cerita Fabel Bermuatan Literasi Moral Menggunakan Media Pop Up untuk Siswa Kelas VII”. Penelitian tersebut bertujuan untuk menghasilkan produk bahan ajar dan media untuk meningkatkan kemampuan menulis teks fabel. Berdasarkan hasil laporan, bahan ajar dan media tersebut mampu menciptakan suasana belajar mandiri dan dapat mengurangi ketergantungan pembelajaran yang dilakukan oleh guru kelas. Penelitian tersebut memiliki perbedaan dengan penelitian ini, yaitu terkait produk yang dikembangkan berupa bahan ajar dan media pembelajaran, sementara penelitian ini mengembangkan buku pengayaan pembelajaran cerita fabel.

Penelitian yang berkaitan dengan literasi pernah dilakukan oleh Puspitasari (2018) dengan judul "Pengembangan Buku Cerita Fantasi Berbasis Literasi Sains pada Tingkat SMP Kelas VII Kota Malang”. Penelitian tersebut bertujuan untuk menghasilkan buku cerita yang memiliki kriteria kelayakan dari segi isi, bahasa dan kegrafikan. Dari hasil uji validitas dan uji lapangan, produk tersebut layak untuk digunakan. Penelitian tersebut memiliki perbedaan dengan penelitian ini, yaitu terkait pengembangan cerita fantasi berbasis literasi sains, sedangkan pada penelitian yang dikembangkan ini berupa buku pengayaan pembelajaran cerita fabel berbasis literasi baca-tulis pada tingkat sekolah dasar.

Tujuan dari penelitian dan pengembangan ini ialah (1) menghasilkan produk berupa buku pengayaan pembelajaran cerita fabel berbasis literasi untuk siswa kelas II sekolah dasar yang memperhatikan kelayakan dari segi isi, sistematika, bahasa, dan ilustrasi, (2) Menguji keefektifan produk buku pengayaan pembelajaran cerita fabel berbasis literasi baca-tulis untuk siswa kelas II Sekolah Dasar, dan (3) mendeskripsikan hasil uji kelayakan dan uji efektifitas produk buku pengayaan pembelajaran cerita fabel berbasis literasi untuk siswa kelas II sekolah dasar. 


\section{METODE}

Model penelitian dan pengembangan yang digunakan dalam penelitian ini mengadopsi dari model pengembangan 4D (four D Model) yang dikembangkan oleh Thiagarajan, Semmel, Melvyn (1974). Model pengembangan 4D merupakan model pengembangan perangkat pembelajaran. Hal yang mendasari pemilihan model 4D ini dikarenakan kesesuaian antara produk yang dihasilkan yaitu buku pengayaan pembelajaran cerita fabel berbasis literasi baca-tulis dengan tahapan prosedur yang harus dipenuhi. Tahapan dari model tersebut ialah (1) Define (pendefinisian), (2) Design (perencanaan), (3) Develop (pengembangan), dan (4) Disseminate (penyebaran).

Sumber data dalam penelitian ini, yaitu ahli pembelajaran cerita fabel, ahli desain grafis, ahli praktisi, dan siswa kelas II sekolah dasar. Pengumpulan data dilakukan dengan menggunakan instrumen lembar validasi, angket penilaian, pedoman wawancara dan tes. Instrumen lembar validasi ditujukan kepada ahli pembelajaran cerita fabel, ahli desain grafis untuk memperoleh penilaian, komentar dan saran guna memperbaiki produk yang dikembangkan. Angket penilaian ditujukan kepada ahli praktisi. Wawancara semiterstruktur dilakukan pada tahap prapengembangan dan pascapengembangan kepada ahli praktisi dan siswa untuk memperoleh komentar dan saran guna kepentingan produk yang dikembangkan. Instrumen tes ditujukan kepada siswa untuk mengetahui tingkat keefektifan dari produk yang dikembangkan. Data penelitian ini berupa data kuantitatif dan data kualitatif. Data kuantitatif berupa data skor yang diperoleh dari instrumen lebar validasi dan angket penilaian. Data kualitatif dibedakan menjadi data tertulis dan data lisan, data tersebut berupa komentar dan saran perbaikan yang diperoleh dari validator ahli dan ahli praktisi.

Analisis data dilakukan secara kualitatif dan kuantitatif. Analisis data kualitatif dilakukan untuk menganalisis data yang diperoleh dari instrumen wawancara serta komentar dan saran yang diberikan oleh validator dan ahli praktisi. Teknik analisis kuantitatif digunakan untuk menganalisis data berupa skor yang diperoleh dari lembar validasi, angket penilaian dan tes dengan cara (1) mengumpulkan data numerik, (2) menganalisis data, (3) merumuskan simpulan analisis sebagai dasar untuk melakukan tindak lanjut. Uji efektivitas produk dilakukan untuk mengetahui tingkat keefektifan produk yang dikembangkan. Uji keefektifan produk dilakukan dengan menggunakan desain pre-experimental jenis one group pretest-posttest design dengan uji $\mathrm{T}$ paired sample t-test dengan asumsi data penyebaran normal. Analisis data dilakukan menggunakan program SPSS 22 for Windows.

\section{HASIL}

Penelitian dan pengembangan ini menghasilkan produk berupa buku pengayaan pembelajaran cerita fabel berbasis literasi baca-tulis untuk siswa kelas II sekolah dasar. Bagian ini dijabarkan tiga hal yang berkaitan dengan temuan penelitian dan pengembangan, yaitu (1) deskripsi produk, (2) hasil uji kelayakan, dan (3) perbaikan produk. Ketiga hal tersebut dijabarkan sebagai berikut.

\section{Deskripsi Produk}

Produk pengembangan ini disusun sebagai buku pendamping yang digunakan oleh siswa dalam proses pembelajaran. Spesifikasi produk ini dibagi menjadi empat aspek, yaitu (1) isi, (2) bahasa, (3) ilustrasi, dan (4) sistematika penyajian. Keempat aspek tersebut dijelaskan sebagai berikut.

Pertama, isi dari produk buku pengayaan pembelajaran cerita fabel berbasis literasi ini dirancang dengan mengacu Kompetensi Dasar (KD) pada Kurikulum 2013 revisi tahun 2017 pada jenjang kelas II sekolah dasar, yaitu KD 3.8 dengan rumusan menggali informasi dari dongeng binatang (fabel) tentang sikap hidup rukun dari teks lisan dan tulis dengan tujuan untuk kesenangan, dan KD 4.8 dengan rumusan menceritakan kembali teks dongeng binatang (fabel) yang menggambarkan sikap hidup rukun yang telah dibaca secara nyaring sebagai bentuk ungkapan diri, sedangkan materi yang dimuat dalam produk ini didasarkan pada buku teks pelajaran yang digunakan oleh siswa. Cerita fabel yang dimuat dalam produk ini disesuaikan dengan kriteria yang dikemukakan oleh Tomlinson dan Brown (2002), yaitu dengan unsur-unsur pembangun cerita fabel yang terdiri dari (1) tema, (2) tokoh, (3) latar, (4) sudut pandang, (5) alur, dan (6) amanat atau pesan moral. Tema cerita pada produk ini disesuaikan dengan materi tematik yang terdapat pada buku teks pelajaran siswa, yaitu kebersamaan di rumah, kebersamaan di sekolah, kebersamaan di tempat bermain, dan kebersamaan di tempat wisata.

Tokoh dan penokohan pada cerita fabel ini menggunakan binatang endemik khas Indonesia sebagai sarana personifikasi dari karakteristik manusia, tokoh utama terdiri dari tiga binatang, yaitu (1) Wiwi adalah sebutan dari burung cenderawasih (Paradisaea Apoda) khas Pulau Papua yang memiliki karakter cerdas dan ahli dalam menentukan keputusan (Gambar 1); (2) Ruru adalah sebutan dari rusa bawean (Hyelaphus Kuhlii) khas dari Pulau Bawean Kabupaten Gresik, Jawa Timur yang memiliki karakter cekatan dan memiliki simbol kecepatan layaknya rusa bawean (Gambar 2); (3) Rhino adalah sebutan dari binatang badak bercula satu (Rhinoceros Sondaicus) khas daerah Ujung Kulon yang memiliki karakter tangguh sehingga memiliki simbol kekuatan (Gambar 3). 


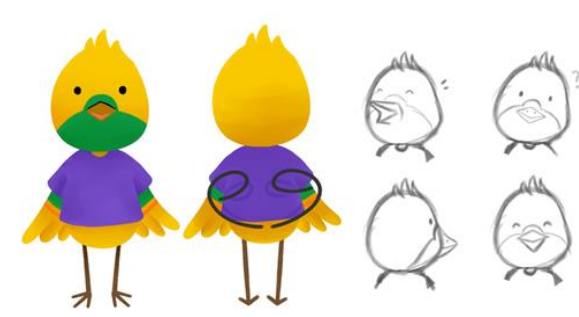

Gambar 1. Profil Wiwi Tokoh Utama Cerita Fabel

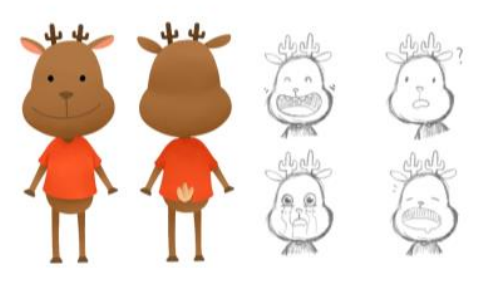

Gambar 2. Profil Ruru Tokoh Utama Cerita Fabel

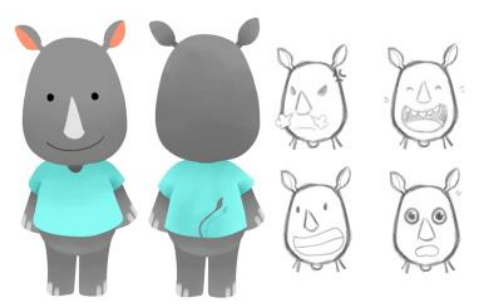

\section{Gambar 3. Profil Rhino Tokoh Utama Cerita Fabel}

Tokoh pembantu dalam cerita fabel ini berperan sebagai pelengkap dengan menggunakan binatang-binatang yang mudah dikenali oleh siswa kelas II sekolah dasar, seperti ayam, anjing, lebah, serigala, dan kelinci. Penyajian cerita memiliki variasi latar waktu dan tempat yang berbeda-beda sehingga memberikan pengalaman yang beragam. Sudut pandang yang digunakan menggunakan sudut pandang orang ketiga dalam penyajian ceritanya. Alur cerita fabel ini terdiri atas empat bagian, yaitu orientasi, komplikasi, resolusi, dan koda. Amanat atau pesan moral pada cerita fabel ini bertujuan untuk menyampaikan nilai-nilai pendidikan karakter baik guna mengembangkan kecerdasan emosi dan sosial siswa. Serial cerita fabel ini memiliki pesan amanat yang berbeda-beda disetiap judulnya. Terdapat pembelajaran nilai karakter utama yang disampaikan pada produk ini, diantaranya kreatif dan inovatif, gemar membaca, sikap kejujuran, saling berbagi, dan peduli lingkungan alam.

Kedua, bahasa penyajian dalam produk ini disesuaikan dengan perkembangan usia pembaca dengan gaya bahasa figuratif serta kaidah bahasa Indonesia baik dari segi penguasaan struktur tata bahasa maupun dari segi kemampuan anak dalam memahaminya. Penggunaan bahasa didasarkan pada Pedoman Umum Ejaan Bahasa Indonesia (PUEBI) yang komunikatif dan sederhana, sehingga dapat mengembangkan kecerdasan linguistik siswa. Penggunaan kalimat komunikatif tersebut didasarkan pada indikator yang dikemukakan oleh Semi (2007) sebagai berikut, (1) kaidah tata bahasa, (2) kelogisan kalimat, (3) kalimat yang singkat dan jelas, (4) kohesi dan koherensi kata yang digunakan, dan (5) kemudahan kalimat untuk dipahami.

Ketiga, desain ilustrasi dalam buku pengayaan ini dicetak secara landscape dengan ukuran kertas standar yang ditetapkan ISO yaitu, A4 (21 cm x 29,7 cm). Jenis kertas yang digunakan pada bagian kulit buku menggunakan jenis Art Carton dengan tebal $190 \mathrm{gsm}$, sedangkan pada bagian isi buku menggunakan Art Paper dengan tebal $120 \mathrm{gsm}$. Pemilihan kertas tersebut bertujuan agar gambar ilustrasi yang ditampilkan terkesan lebih detail dan menghindari warna tinta agar tidak tembus pada halaman berikutnya. Selain itu, supaya buku lebih aman dan tidak mudah robek jika digunakan oleh siswa. Sementara itu, desain ilustrasi gambar dan warna disajikan secara penuh dengan tujuan untuk mengembangkan kecerdasan visual siswa. Penomoran halaman menggunakan gambar yang terletak pada pojok kanan bawah. Jenis huruf pada isi cerita menggunakan jenis Andika Basic dengan ukuran 16 pt, sedangkan untuk judul unit menggunakan jenis huruf Bauhaus 93 dengan ukuran 48 pt dan Cooper Black ukuran 28 pt, sementara pada judul sampul menggunakan Vedemecum, Mail Rail Stuff, dan Humanst 521 XBt BT. 
Keempat, sistematika penyajian dalam produk buku pengayaan pembelajaran cerita fabel berbasis literasi ini disajikan secara serial. Di akhir masing-masing bagian cerita terdapat latihan pertanyaan yang harus dikerjakan oleh siswa. Aktivitas latihan yang termuat dalam produk buku pengayaan pembelajaran cerita fabel berbasis literasi baca-tulis ini didasarkan pada olahan PIRLS 2006 Topping (2006) yang memuat empat komponen utama, yaitu (1) kemampuan siswa untuk mengulang kembali informasi yang dibacanya, (2) membuat inferensi langsung, (3) menginterprestasikan ide gagasan, dan (4) menganalisa dan mengevaluasi konten dari bahan bacaan. Aktivitas latihan yang dikembangkan ini bertujuan untuk menuntun pemahaman siswa terhadap isi bacaan cerita fabel. Sistematika dari penyajian buku pengayaan ini terdiri dari empat bagian, yaitu (1) bagian kulit, (2) bagian pendahuluan, (3) bagian inti, dan (4) bagian akhir. Penjelasan dari keempat komponen produk tersebut sebagaimana ditunjukkan pada Tabel 1 .

Tabel 1. Sistematika Penyajian Buku Pengayaan Pembelajaran Cerita Fabel Berbasis Literasi Baca-Tulis

\begin{tabular}{ll}
\hline Komponen & \multicolumn{1}{c}{ Keterangan } \\
\hline Sampul Depan & Bagian Kulit \\
Punggung Buku & $\begin{array}{l}\text { Memuat judul buku yang mengacu pada isi dari cerita fabel dengan variasi warna dan } \\
\text { gambar yang memberikan ilustrasi menarik } \\
\text { Memuat identitas penerbit atau logo dari instansi, nama pengembang, judul dan tahun } \\
\text { penerbitan }\end{array}$ \\
\hline Kata Pengantar & \multicolumn{1}{c}{ Bagian Pendahuluan } \\
Petunjuk Penggunaan & Memuat kata sambutan dan motivasi dari penulis \\
Daftar Isi & Memuat petunjuk penggunaan yang ditujukan pada pendamping \\
\hline & Memuat kerangka (Outline) buku dengan nomor halaman \\
\hline Karnaval Hari & \multicolumn{1}{c}{ Bagian Inti } \\
Kemerdekkaan & Cerita fabel dengan pembelajaran karakter kreatif dan inovatif \\
Berwisata di Toko Buku & Cerita fabel dengan pembelajaran karakter gemar membaca \\
Jujur Itu Menyenangkan & Cerita fabel dengan pembelajaran karakter kejujuran dan disiplin \\
Berbagi Lebih Asikku Suka Berkebun & Cerita fabel dengan pembelajaran karakter saling berbagi \\
\hline \multicolumn{2}{l}{ Cerita fabel dengan pembelajaran karakter peduli lingkungan } \\
\hline Profil Pengembang & Bagian akhir \\
Sampul Belakang & Memuat identitas pengembang dan latar belakang pendidikannya \\
\hline
\end{tabular}

\section{Hasil Uji Kelayakan Produk}

Hasil uji kelayakan ini melibatkan ahli validasi, ahli parktisi dan siswa kelas II sekolah dasar. Hasil penilaian yang dilakukan kepada ahli pembelajaran cerita fabel dan ahli desain grafis meliputi aspek isi cerita dengan persentase skor $85 \%$ (sangat layak), aspek sistematika penyajian 85\% (sangat layak), aspek bahasa 69\% (cukup layak), dan aspek desain grafis dengan persentase skor $88 \%$ (sangat layak). Uji kelayakan yang dilakukan terhadap ahli praktisi memperoleh hasil pencapaian indikator yang meliputi aspek kurikulum dengan persentase skor $100 \%$ (sangat layak), isi materi $81 \%$ (layak), pembelajaran $87 \%$ (sangat layak), interaksi $91 \%$ (sangat layak), dan aspek umpan balik dengan persentase skor $87 \%$ (sangat layak). Data verbal yang diperoleh dari hasil uji kelayakan berupa komentar dan saran perbaikan produk. Aspek yang perlu diperbaiki, seperti (1) penggunaan bahasa yang lebih komunikatif, (2) memberikan sampul judul pada masing-masing bagian cerita, (3) menggunakan jenis huruf yang lebih menarik, dan (4) memperbaiki diksi yang sesuai dengan kriteria siswa kelas II SD.

Hasil uji kelayakan juga di peroleh dari uji coba kepada siswa kelas II SDS Wahidiyah Kota Kediri dengan tujuan untuk memperoleh respon dari siswa terhadap produk yang dikembangkan. Data yang diperoleh dari kegiatan tersebut berupa data verbal melalui kegiatan wawancara semi terstruktur. Hasil analisis dapat disimpulkan bahwasanya secara keseluruhan siswa menyukai buku pengayaan cerita fabel berbasis literasi baca-tulis ini, alasan mereka menyukai produk tersebut dikarenakan (1) ceritanya bagus dan memiliki judul cerita yang banyak, (2) ceritanya bagus dengan tokoh yang lucu, (3) ceritanya menyenangkan karena mengandung pembelajaran, (4) bahasanya mudah dipahami dan tidak sulit, dan (5) dapat mengidolakan tokoh yang ada didalam cerita, seperti Rhino dan Wiwi.

\section{Hasil Uji Keefektifan Produk}

Uji keefektifan produk dilakukan untuk mengetahui tingkat keefektifan produk yang dikembangkan. Uji keefektifan produk dilakukan dengan menggunakan desain pre-experimental jenis one group pretest-posttest design dengan uji $\mathrm{T}$ paired sample t-test dengan asumsi data penyebaran normal. Analisis data dilakukan menggunakan program SPSS 22 for Windows. Data pretest dan postest kemudian dianalisis melalui uji normalitas dan uji beda. Dasar pengambilan keputusan dalam teknik ini, apabila nilai signifikansi (2-tailed) $<0,05$, maka terdapat perbedaan yang signifikan antara hasil data pretest dan postest, sedangkan apabila nilai signifikansi $(2$-tailed $)>0,05$, maka tidak terdapat perbedaan yang signifikan pada data pretest dan postest. Hasil uji normalitas dan uji beda diuraikan sebagaimana ditunjukkan pada Tabel 2. 
Tabel 2. Hasil Uji Normalitas One-Sample Kolmogorov-Smirnov Test

\begin{tabular}{llc}
\hline $\mathrm{N}$ & & 22 \\
\hline Normal Parameters & & \\
& Mean & 89.64 \\
Most Extreme Differences & Std. Deviation & 6.130 \\
& Absolute & .151 \\
& Positive & .151 \\
& Negative & -.105 \\
\hline Test Statistic & & .151 \\
Asymp. Sig. (2-tailed) & & $.200^{\mathrm{c}, \mathrm{d}}$ \\
\hline
\end{tabular}

Hasil uji normalitas tersebut bertujuan untuk memperoleh nilai residual berdistribusi normal atau tidak. Dasar pengambilan keputusan dapat dilihat apabila nilai signifikan $>0,05$ maka nilai signifikan berdistribusi normal, namun apabila nilai signifikan $<0,05$ maka nilai residual tidak berdistri normal. Berdasarkan Tabel 2 tersebut, hasil perhitungan uji kolmogrovsmirnov test diperoleh nilai signifikansi sebesar 0,200>0,05, maka dapat disimpulkan nilai residual berdistribusi normal. Langkah berikutnya ialah uji beda menggunakan teknik paired sample t-test untuk mengetahui apakah terdapat perbedaan antara pretest dan postest dengan sampel yang sama. Berikut disajikan hasil uji beda data pretest dan posttest (Tabel 3).

Tabel 3. Hasil Uji Beda Sampel Statistik Data Pretest dan Postest

\begin{tabular}{llllll}
\hline & & Mean & N & Std. Deviation & Std. Error Mean \\
\hline \multirow{2}{*}{ Pair 1 } & Pretest & 78.1818 & 22 & 4.40386 & .93891 \\
& Postest & 89.6364 & 22 & 6.12991 & 1.30690 \\
\hline
\end{tabular}

Hasil uji beda pada Tabel 3 tersebut menunjukkan ringkasan statistik data mean pretest sebesar 78.1818, sedangkan mean postest sebesar 89.6364 dengan jumlah sampel 22 siswa. Hal tersebut membuktikan bahwa terdapat perbedaan antara hasil pretest dengan posttest (Tabel 4).

Tabel 4. Hasil Uji Beda Sampel Tes Data Pretest dan Postest

\begin{tabular}{|c|c|c|c|c|c|c|c|c|}
\hline & & \multicolumn{5}{|c|}{ Paired Differences } & \multirow{3}{*}{$\mathrm{t}$} & \multirow{3}{*}{ df $\begin{array}{c}\text { Sig. } \\
\text { (2-tailed) }\end{array}$} \\
\hline & & \multirow[t]{2}{*}{ Mean } & \multirow{2}{*}{$\begin{array}{c}\text { Std. } \\
\text { Deviation }\end{array}$} & \multirow{2}{*}{$\begin{array}{l}\text { Std. } \\
\text { Error Mean }\end{array}$} & \multirow{2}{*}{$\begin{array}{l}95 \% \\
\text { Interval of the } \\
\text { Lower }\end{array}$} & $\begin{array}{l}\text { Confidence } \\
\text { Difference } \\
\end{array}$ & & \\
\hline & & & & & & Upper & & \\
\hline Pair 1 & $\begin{array}{r}\text { Pretest } \\
\text { - Postest }\end{array}$ & -11.45455 & 5.42242 & 1.15606 & -13.85871 & -9.05038 & -9.908 & .000 \\
\hline
\end{tabular}

Dasar pengambilan keputusan dalam teknik ini dijelaskan, apabila nilai signifikansi (2-tailed) $<0,05$, maka terdapat perbedaan yang signifikan antara hasil data pretest dan postest, sedangkan apabila nilai signifikansi $(2$-tailed $)>0,05$, maka tidak terdapat perbedaan yang signifikan pada data pretest dan postest. Berdasarkan Tabel 4, dapat diketahui bahwa nilai signifikansi (2-tailed) sebesar 0,000<0,05, maka dapat disimpulkan bahwa terdapat perbedaan antara data pretest dan postest. Hasil tersebut membuktikan bahwa produk yang dikembangkan dapat dikategorikan efektif untuk diimplementasikan.

\section{Perbaikan Produk}

Perbaikan produk buku pengayaan pembelajaran cerita fabel berbasis literasi ini dilakukan melalui dua tahap. Tahap perbaikan pertama dilakukan berdasarkan penilaian serta komentar dan saran dari ahli validasi pembelajaran cerita fabel dan ahli validasi desain grafis, sedangkan perbaikan tahap kedua dilakukan berdasarkan penilaian serta komentar dan saran dari praktisi. Perbaikan tahap pertama mencakup hasil penilaian dari ahli validasi yang meliputi (1) memperbaiki sasaran kata pengantar, (2) memperbaiki penggunaan bahasa yang disesuaikan dengan kualifikasi bahasa siswa, (3) memberikan judul pembatas antara bagian cerita satu dengan yang lain, (4) memberikan pengenalan dari masing-masing tokoh pada bagian awal, (5) menggunakan hard cover agar produk lebih aman dan tidak mudah robek ketika digunakan oleh siswa dan (6) memperbaiki bagian latihan dengan menggunakan bahasa yang lebih komunikatif.

Perbaikan pada tahap kedua dilakukan berdasarkan penilaian serta komentar dan saran dari ahli praktisi. Adapun perbaikan yang dilakukan pada tahap kedua ini, meliputi (1) memperbaiki ejaan yang terdapat pada halaman 4 dan halaman 52, dan (2) memperbaiki tata letak teks pada halaman 4 agar tidak membingungkan pembaca. Produk pengembangan yang telah diperbaiki dapat dinyatakan layak untuk disebarkan sehingga dapat dimanfaatkan oleh lembaga pendidikan sekolah dasar khususnya kelas II untuk dijadikan sebagai buku pendamping dalam proses pembelajaran di sekolah. 


\section{PEMBAHASAN}

Produk yang dihasilkan dari penelitian dan pengembangan ini berupa buku pengayaan pembelajaran cerita fabel berbasis literasi baca-tulis untuk siswa kelas II sekolah dasar. Produk ini ditujukan untuk dijadikan sebagai buku pendamping yang digunakan oleh siswa dalam proses pembelajaran. Produk yang dikembangkan ini telah memenuhi kriteria kelayakan melalui uji validasi, uji praktisi dan uji coba kepada siswa. Hal tersebut dilakukan agar produk yang dikembangkan memang layak untuk diimplementasikan dan disebarluaskan. Berikut diuraikan mengenai kajian uji coba produk dan kebermanfaatan produk.

\section{Kajian Uji Coba Produk}

Prinsip dalam mengembangkan buku pengayaan perlu memperhatikan komponen-komponen utamanya. Menurut Prastowo (2013) komponen tersebut berhubungan dengan materi atau isi buku, penyajian materi, bahasa, dan kegrafikaan. Produk buku pengayaan cerita fabel berbasis literasi baca-tulis ini dalam proses pengembangannya juga memperhatikan kriteria kelayakan yang meliputi (1) aspek isi cerita, (2) aspek sistematika penyajian, (3) aspek bahasa, dan (4) aspek desain grafis. Buku pengayaan cerita fabel berbasis literasi baca-tulis ini telah dinyatakan layak untuk dimanfaatkan oleh berbagai pihak guna mengatasi ketersediaan buku penunjang yang ada di sekolahan. Produk ini memiliki struktur teks yang sudah disesuaikan dengan kriteria siswa kelas II sekolah dasar. Tampilan ilustrasi yang disajikan juga dirancang secara menarik agar siswa antusias untuk membacanya.

Berdasarkan hasil analisis uji kelayakan ditemukan bahwa minat siswa terhadap buku pengayaan cerita fabel berbasis literasi baca-tulis ini sangat tinggi. Salah satu indikator dari tingginya minat siswa adalah perilaku ketertarikan siswa yang dapat dilihat dari reaksi mereka ketika diberi kesempatan untuk melihat-lihat bagian buku, seperti judul sampul, daftar isi cerita dan beberapa isi cerita. Minat yang sangat tinggi dari siswa dimungkinkan karena tampilan buku seperti banyaknya ilustrasi gambar dan warna yang mencolok, serta penyajian isi cerita yang cukup memikat juga turut mendukung kuatnya minat siswa terhadap produk yang dikembangkan. Kuatnya minat baca siswa, mengindikasikan bahwa produk ini dapat membangkitkan kesenangan siswa sebagaimana dikatakan oleh Heath dan Smith (2017) bahwa salah satu daya tarik sastra anak adalah fungsinya yang dominan memberikan hiburan melalui daya imajinasi dan memberikan manfaat bagi pembaca sehingga timbul rasa kesenangan. Produk ini juga terbukti efektif, berdasarkan uji menggunakan teknik paired sample t-test, diperoleh ringkasan statistik mean pretest sebesar 78.18, sedangkan mean postest sebesar 89.63 dengan jumlah sampel 22 siswa.

\section{Kajian Kebermanfaatan Produk}

Buku pengayaan cerita fabel berbasis literasi baca-tulis ini disusun untuk dapat membantu siswa agar mengetahui dan menyadari pentingnya nilai-nilai pendidikan karakter, serta melatih dan memberikan kesempatan kepada siswa untuk merefleksikan atas pengalamannya dalam melaksanakan sikap-sikap baik tersebut. Hal tersebut sesuai dengan penjelasan Milson dan Mehlig (2002) bahwa untuk membangun pendidikan karakter perlu dilakukan secara serentak antara pengembangan pengetahuan moral, perasaan moral, dan tindakan moral. Produk ini memuat beberapa pendidikan karakter seperti (1) kreatif dan inovatif, (2) gemar membaca, (3) perilaku jujur, (4) gemar berbagi, dan (5) peduli terhadap lingkungan alam yang menarik disisipkan melalui subjudul dari cerita yang disajikan secara beragam sehingga dapat memberikan inspirasi bagi siswa untuk merefleksikan pengalamannya dalam melaksanakan sikap-sikap baik dalam kehidupan nyata.

Tuntutan kemampuan kemahirwacanaan siswa sekolah dasar adalah berkembangnya potensi berbahasa individu. Kemampuan berbahasa tersebut mencakup aspek (1) interaksional, penggunaan bahasa untuk berinteraksi dengan orang lain, (2) personal, penggunaan bahasa untuk mengekspresikan gagasan atau perasaan, (3) imajinatif, penggunaan bahasa untuk mengembangkan daya khayal, dan (4) fungsi representasional, penggunaan bahasa untuk mengomunikasikan informasi. Buku pengayaan cerita fabel ini disusun menggunakan berbasis literasi, sehingga dapat membantu dan melatih kemampuan kemahirwacanaan siswa. Menurut Pratiwi (2016) melalui pertanyaan latihan yang dikembangkan secara berjenjang sesuai dengan perkembangan kognitif, dapat mendorong siswa berpikir kritis. Pertanyaan-pertanyaan yang disajikan di akhir masing-masing cerita pada produk ini, bertujuan untuk menuntun siswa dalam menggali informasi yang terdapat pada bacaan. Hal tersebut membenarkan pendapat Hayat dan Yusuf (2010), bahwa untuk mengungkap seberapa jauh tingkat pemahaman siswa terhadap isi wacana yang telah dibaca dapat dilakukan dengan latihan menanggapi isi wacana atau menjawab soal. Mengingat Nurchasanah dan Sunaryo (2016) bahwa pentingnya melatih kemampuan literasi dalam rangka untuk mengembangkan pengetahuan serta potensi diri. Produk ini dikembangkan berdasarkan kebutuhan akan buku penunjang yang ada dilapangan. Minimnya bahan bacaan cerita fabel berbasis literasi baca-tulis yang memuat nilai-nilai pendidikan karakter membuat perlu dilakukan pemecahan masalah dengan menghadirkan alternatif solusi berupa pengembangan produk buku cerita fabel berbasis literasi baca-tulis. Upaya pemanfaatan dan penyebarluasan produk ini dikarenakan masih jarang dijumpai buku pengayaan atau bahan bacaan yang berbasis literasi dan memperhatikan aspek kelayakan dari segi isi, bahasa, sistematika penyajian, dan desain ilustrasi yang sesuai dengan karakteristik siswa kelas II sekolah dasar. 


\section{SIMPULAN}

Berdasarkan paparan di atas, dapat diperoleh dua simpulan. Pertama, produk yang dihasilkan dalam penelitian dan pengembangan ini berupa buku pengayaan pembelajaran cerita fabel berbasis literasi baca-tulis untuk siswa kelas II sekolah dasar. Produk ini telah teruji dari segi kelayakan yang meliputi aspek isi, sistematika penyajian, penggunaan bahasa, dan desain ilustrasi. Kedua, produk pengembangan ini memiliki kegunaan untuk dijadikan sebagai buku penunjang proses pembelajaran baik di sekolah mapuan di rumah, selain dapat digunakan sebagai sarana pemahaman nilai-nilai pendidikan karakter dan melatih kemampuan kemahirwacanaan siswa, produk ini dapat dijadikan sebagai sarana hiburan untuk menggairahkan daya imajinasi siswa dengan tujuan untuk kesenangan.

Berdasarkan hasil penelitian dan pengembangan yang telah diuraikan, dapat dikemukakan saran yang ditujukan kepada guru, orangtua, dan peneliti selanjutnya. Pertama, kepada lembaga pendidikan sekolah dasar khususnya kelas II agar dapat memanfaatkan buku pengayaan dalam proses pembelajaran sehingga dapat mengoptimalkan tujuan pembelajaran yang hendak dicapai. Kedua, produk ini juga disarankan untuk dapat digunakan oleh orangtua di rumah sebagai sarana hiburan dan pemahaman Pendidikan karakter serta kemampuan kemahirwacanaan siswa. Ketiga, kepada peneliti selanjutnya, apabila ditinjau dari kebutuhan akan buku pengayaan di lapangan, produk ini tidak memungkinkan dapat menjangkau semua materi yang dibelajarkan di sekolah. Oleh karena itu, sangat memungkinkan apabila penelitian dan pengembangan produk yang sejenis dapat dilakukan lebih lanjut dengan menghadirkan genre cerita yang lebih bervariasi.

\section{DAFTAR RUJUKAN}

Hasanah, M. (2012). Model Cerita Fiksi Kontemporer Anak-Anak untuk Pengembangan Kemahirwacanaan Siswa Kelas V Sekolah Dasar. Litera: Jurnal Penelitian Bahasa, Sastra, dan Pengajarannya, 11(1), 95-110. https://doi.org/10.21831/ltr.v11i1.1150

Heath, M. A., Smith, K., \& Young, E. L. (2017). Using Children's Literature to Strengthen Social and Emotional Learning. School Psychology International, 38(5), 541-561. https://doi.org/10.1177/0143034317710070

Kathy, E., \& Rebecca, L. T. (2007). Across Cultures A Guide to Multicultural Literature for Children. London: Libraries Unlimited.

Kuo, S. H. (2012). The Art of Making Animals Laugh Benjamin Rabier's Comic-Illustration of Les Fables de La Fontaine. Neophilologus, 97(1), 21-33. https://doi.org/10.1007/s11061-012-9310-8

Marcum-Dietrich, N. (2007). Learning Through Stories. National Science Teachers Association, 74(4), 52-54.

Maureen, I. Y., van der Meij, H., \& de Jong, T. (2018). Supporting Literacy and Digital Literacy Development in Early Childhood Education Using Storytelling Activities. International Journal of Early Childhood, 50(3), 371-389. https://doi.org/10.1007/s13158-018-0230-z

Milson, A. J., \& Mehlig, L. M. (2002). Elementary School Teachers' Sense of Efficacy for Character Education. Journal of Educational Research, 96(1), 47-53. https://doi.org/10.1080/00220670209598790

Nurchasanah., \& Sunaryo, H. S. (2016). Perangkat Perkuliahan Pembelajaran Literasi Berbasis E-Learning. Jurnal Bahasa dan Seni, 44(2), 224-240.

Parkinson, J., \& Adendorff, R. (2005). Science books for children as a preparation for textbook literacy. Discourse Studies, 7(2), 213-236. https://doi.org/10.1177/1461445605050367

Prastowo, L. (2013). Panduan Kreatif Membuat Bahan Ajar Inovatif. Yogyakarta: Diva Press.

Pratiwi, Y. (2016). Film Animasi Cerita dengan Konteks Multibudaya untuk Mendukung Pengembangan Kekritisan Penalaran Anak Usia SD. Litera: Jurnal Penelitian Bahasa, Sastra, dan Pengajarannya, 15(2), 292-304. https://doi.org/10.21831/ltr.v15i2.11830

Semi, M. A. (2007). Dasar-dasar Keterampilan Menulis. Bandung: Magantara.

Suyono. (2009). Pembelajaran Efektif dan Produk Berbasis Literasi: Analisis Konteks, Prinsip, dan Wujud Alternatif Strategi Implementasinya di Sekolah. Jurnal Bahasa dan Seni, 37(2), 203-217.

Tomlinson, C. M., \& Brown, C. (2002). Essential of Children's Literature. Boston: Ablogman.

Topping, K. (2006). PISA/PIRLS Data on Reading Achievement: Transfer Into International Policy and Practice. The Reading Teacher, 59(6), 588-590. https://doi.org/10.1598/rt.59.6.9 